\title{
Dinasti-isme: Demokrasi, Dominasi Elit, dan Pemilu
}

\author{
Wawan Gunawan \\ Dosen Prodi Magister Ilmu Pemerintahan \\ Universitas Jenderal Achmad Yani \\ Cimahi
}

\begin{abstract}
Abstrak
Tulisan ini mendiskusikan tentang dinastiisme dalam Pemilihan Umum Kepala Daerah yang dilatarbelakangi oleh kehadiran anggota keluarga petahana dalam Pemilukada. Dinastiisme merupakan istilah yang digunakan penulis untuk menggambarkan tentang isme atau aliran dalam dinasti politik, dengan demikian pemaknaan dinastiisme petahana, dalam tulisan ini, merupakan istilah lain dari dinasti politik petahana. Selanjutnya dilakukan diskursus melalui beberpa konsep: Demokrasi, dominasi elit, serta pemilu.
\end{abstract}

Kata Kunci: Dinasti politik petahana dan pemilihan umum kepala daerah.

\begin{abstract}
This paper discusses dynasticism in the Regional Head General Election which is motivated by the presence of incumbent family members in the General Election. Dynastyism is a term used by the author to describe the ism or flow in political dynasties, thus the meaning of incumbent dynastyism, in this paper, is another term for incumbent political dynasty. Furthermore, the discourse was carried out through several concepts: Democracy, elite domination, and elections.
\end{abstract}

Keywords: incumbent political dynasty and regional head elections

\section{PENDAHULUAN}

Dalam sistem pemerintahan yang berlandaskan demokrasi maka setiap orang diperbolehkan untuk memilih dan dipilih melalui mekanisme pemilihan umum. Oleh sebab itulah maka dinastiisme menjadi sulit dihindari. Maraknya fenomena istri walikota atau istri bupati mencalonkan diri dan terpilih, atau seorang menantu menggantikan posisi mertuanya dalam posisinya sebagai bupati, merupakan fenomena dinastiisme dalam sistem pemerintahan di banyak negara termasuk di Indonesia. 
Fenomena ini menjadi menarik karena terjadi saat masyarakat sedang gencar-gencarnya melakukan kritik terhadap praktik dinastiisme (Kusni, 2012; Ayu, dkk., 2012; Ilyas, 2012). Selain itu, karena dinastiisme cenderung dianggap negatif dalam sebuah sistem pemerintahan sedangkan demokrasi sendiri memberikan ruang kepada petahana untuk bisa mencalonkan salah seorang anggota keluarganya (Werdiningsih, 2012). Bahkan, deliberasi ${ }^{1}$ politik dalam sebuah sistem pemerintahan membuka ruang kontestasi untuk siapa pun, termasuk menciptakan dinastiisme dari petahana ${ }^{2}$ untuk turut bersaing dalam pemilihan kepala daerah. Tentu akan ada dugaan bahwa sulit dihindari hegemoni petahana dalam proses tersebut.

Fenomena dinastiisme dalam sistem pemerintahan daerah sudah banyak yang mengkajinya (Lihat misalnya: Fuady, 2010; Soemiarno, 2010; Djohan, 2011; Bathoro, 2011; Faizal, 2012; Ilyas, 2012; Soleh, 2012; Muhtadi, 2012; Alhumami, 2012; Prabadipta, 2012; Sarwi, 2012). Namun demikian, penelitianpenelitian tersebut lebih melihat dinastiisme dari sisi politik dan sosial pada umumnya, yaitu dianggap mencederai sistem demokrasi.

\section{TINJAUAN PUSTAKA}

\section{Konsep Demokrasi}

Pemerintahan yang demokratis tentu akan merujuk kepada konsep demokrasi yang evolutif dan dinamis sesuai dengan konteks dan dinamika sosio historisnya ${ }^{3}$. Demokratisasi (democratization) diartikan sebagai the act or

1 Kata deliberasi berasal dari kata Latin deliberatio yang artinya konsultasi, musyawarah, atau menimbangnimbang. Demokrasi bersifat deliberatif jika proses pemberian alasan atas suatu kandidat kebijakan publik diuji lebih dahulu lewat konsultasi publik, atau diskursus publik. Demokrasi deliberatif ingin meningkatkan intensitas partisipasi warga negara dalam proses pebentukan aspirasi dan opini agar kebijakan-kebijakan dan undang-undang yang dihasilkan oleh pihak yang memerintah semakin mendekati harapan pihak yang diperintah. Intensifikasi proses deliberasi lewat diskursus publik ini merupakan jalan untuk merealisasikan konsep demokrasi, Regierung der Regierten (pemerintahan oleh yang diperintah). Demokrasi deliberatif memiliki makna tersirat yaitu diskursus praktis, formasi opini dan aspirasi politik, serta kedaulatan rakyat sebagai prosedur. Lebih jelas lihat F. Budi Hardiman, Demokrasi Deliberatif, Yogyakarta: Kanisius, 2009, Hlm. 126-128.

2 Petahana (bahasa Inggris: incumbent), berasal dari kata "tahana", yang berarti kedudukan, kebesaran, atau kemuliaan, dalam politik, adalah pemegang suatu jabatan politik yang sedang menjabat. Istilah ini biasanya digunakan dalam kaitannya dengan pemilihan umum. Kata ini pertama kali diperkenalkan oleh Salomo Simanungkalit pada tanggal 6 Februari 2009 sebagai padanan kata dalam konteks Pemilihan umum Presiden Indonesia 2009. Selengkapnya lihat Wikipedia ensiklopedia bebas.

3 Ahmad Suhelmi, Pemikiran Politik Barat, Jakarta: Gramedia Pustaka Utama, 2000: 297 
process of making or becoming democratic (menggambarkan serangkaian gerak perkembangan atau proses menuju tercapainya demokrasi) ${ }^{4}$. Konsep demokrasi ${ }^{5}$ sebagai suatu bentuk pemerintahan sudah lama dikenal, yang diperkirakan pertama kali diterapkan di Yunani kuno, sekitar 2500 tahun lalu.

Demokrasi yang dianggap sebagai government by the people ${ }^{6}$ ternyata menyediakan ruang dan kesempatan terjadinya dinastiisme. Munculnya dinastiisme dari perspektif demokrasi disebabkan karena konsep demokrasi memberikan peluang dan kesempatan yang sama terhadap siapapun untuk dapat dipilih dan memilih. Artinya, ketika rakyat sudah menentukan pilihannya terhadap salah seorang anggota keluarga patahana maka itu tidak bertentangan dengan demokrasi asal melalui mekanisme pemilihan umum.

Pemilu dalam demokrasi seringkali dianggap sebagai demokrasi prosedural sebab hal itu merupakan sarat agar tercipta peluang dan kesempatan terjadinya sirkulasi kekuasaan, sehingga pihak mayoritas (massa), dalam hal ini rakyat sebagai pihak yang dikuasai, memiliki kesempatan untuk dipilih dalam kompetisi pemilu menjadi bagian dari pihak minoritas (elit) sebagai pihak yang berkuasa. Di sisi lain, ada yang disebut demokrasi esensial ${ }^{7}$ dimana kedaulatan berada di tangan rakyat, dan ini jauh lebih penting sebab demokrasi prosedural dapat direkayasa, entah melalui money politik atau penyalahgunaan kekuasaan.

Perkembangan kajian demokratisasi membawa perubahan perspektif dalam tiga aspek, yakni pertama, perluasan kesempatan bagi masyarakat untuk berpartisipasi dalam pembuatan keputusan; kedua, perluasan ruang lingkup (scope) isu yang menjadi bahan perdebatan dalam pemerintahan; dan ketiga, kontrol masyarakat yang lebih nyata terhadap penyelenggaraan pemerintahan dengan melibatkan aktor-aktor yang otonom dan kompeten ${ }^{8}$.

4 Tommi A. Legowo. 1994. "Demokratisasi : Refleksi Kekuasaan yang Transformatif" Analisis. Tahun XXIII No. 1 , hal. 5

5 Robert A. Dahl. 2001. Perihal Demokrasi, terj. A. Rahman Zainuddin. Jakarta: YOI. Hlm. 9.

6 Budiardjo, Miriam, Masalah Kenegaraan, Gramedia, Jakarta, 1980:105.

7 Esensi demokrasi bahwa kedaulatan politik ada di tangan rakyat, namun bukan berarti demokrasi sebagai alat untuk menutupi suatu sistem politik yang didalamnya samasekali tidak sesuia dengan nilai nilai hakiki dari demokrasi itu sendiri. Selengkapnya: Alfian, 1982. Politik, Kebudayaan, dan Manusia Indonesia. Jakarta: LP3ES. Hlm. 59.

8 John Dryzek. 2000. Deliberative Democracy And Betond : Liberals, Critics, Contestations. Oxford: Oxford University Press, hal. 29 
Dahl $^{9}$ merumuskan lembaga-lembaga politik dalam pemerintahan demokrasi perwakilan moderen sebagai berikut:

1) Kendali pemerintah berada di tangan pejabat yang dipilih warga negara; 2) Pejabat terpilih ditentukan melalui pemilihan umum;3) Warga negara berhak menyatakan pendapat tanpa bahaya hukuman; 4); Warga negara bebas mencari sumber informasi alternatif; 5) Warga negara bebas berorganisasi termasuk dalam partai politik; 6) Warga negara berhak memberikan suara untuk memilih para pejabat dalam pemilihan umum yang bebas dan adil; hak untuk mencalonkan diri dalam pemilihan; hak untuk bebas berpendapat; hak untuk membentuk dan berpartisipasi dalam organisasi politik; hak untuk mendapatkan sumber informasi yang bebas; dan hak untuk berbagai kebebasan dan kesempatan lainnya yang mungkin diperlukan bagi keberhasilan tindakan lembaga-lembaga politik pada demokrasi skala besar.

Wewenang untuk mengatur dan mengurus urusan pemerintah tidak semata-mata dilakukan oleh pemerintah pusat, melainkan dilakukan juga oleh satuan-satuan pemerintah yang lebih rendah diserahi dan dibiarkan mengatur sendiri sebagian urusan pemerintah. ${ }^{10}$

Pemerintah yang sedang berkuasa memiliki fungsi berdiri di atas semua kepentingan, yang oleh Rasyid ${ }^{11}$ tugas pokok pemerintahan yaitu: Pelayanan (service), pemberdayaan (empowerment), dan pembangunan (development). Pelayanan akan membuahkan keadilan dalam masyarakat, pemberdayaan akan mendorong kemandirian masyarakat, dan pembangunan akan menciptakan kemakmuran dalam masyarakat.

Sedangkan menurut $\mathrm{Ndraha}^{12}$ fungsi pemerintahan yaitu:

Pertama, pemerintah mempunyai fungsi primer atau fungsi pelayanan (service), sebagai provider jasa publik yang baik diprivatisasikan dan layanan civil termasuk layanan birokrasi. Kedua, pemerintah mempunyai fungsi sekunder atau fungsipemberdayaan (empowerment), sebagai penyelenggara pembangunan dan melakukan program pemberdayaan.

Mengacu kepada beberapa pendapat pakar tersebut di atas, terlihat bahwa sebab-sebab dinastiisme dari perspektif demokrasi, adalah sebagai berikut:

1. Demokrasi membolehkan siapapun untuk memilih dan dipilih;

9 Robert A. Dahl, hal. 118-120

${ }^{10}$ Agussalim Andi Gadjong, 2007. Pemerintah Daerah. Bogor: Ghalia Indonesia. Hlm. 79 .

11 Rasyid, M. Ryaas.2000. Makna Pemerintahan, Jakarta : Yarsif Watampone. Hlm. 59

12 Ndraha, Taliziduhu.2000. Ilmu Pemerintahan (kybernology), Rineka Cipta, Jakarta. Hlm. 85 
2. Pemilihan umum dalam demokrasi akan melahirkan kelas penguasa, dan setiap kelas penguasa memiliki kecenderungan untuk mempertahankan kekuasaannya, salah satunya melalui politik dinasti.

3. Setiap kekuasaan cenderung korup, dan karenanya, petahana yang terpilih melalui mekanisme pemilu, berkepentingan "menutupi" penyalahgunaan kekuasaannya dengan jalan mendorong salah seorang anggota keluarganya untuk meneruskan tampuk kekuasaannya melalui pemilu sebagai cara yang dibolehkan dalam sistem demokrasi.

\section{Dominasi Elit}

Dari perspektif teori dominasi kemunculan dinastiisme disebabkan karena adanya peluang dominasi dari kelas penguasa terhadap kelas yang dikuasai. Gaetano Mosca dalam karyanya yang terkenal The Rulling Class $^{13}$ menyatakan bahwa:

Dalam setiap masyarakat terdapat dua kelas penduduk. Satu kelas yang menguasai dan satu kelas yang dikuasai. Kelas pertama yang jumlahnya selalu lebih kecil, menjalankan semua fungsi politik, memonopoli kekuasaan, dan menikmati keuntungan yang diberikan oleh kekuasaan itu, sedangkan kelas kedua, yang jumlahnya jauh lebih besar, diatur dan dikendalikan oleh kelas pertama. ${ }^{14}$

Pandangan tersebut menggambarkan bahwa dalam masyarakat terdapat dua kelas yang menonjol, yaitu kelas yang memerintah dan yang diperintah. Kelas pertama yang menguasai fungsi politik, yakni monopoli kekuasaan sekaligus menguasai hasil-hasilnya. Kelas kedua sebaliknya, mereka yang jumlahnya besar tetapi tidak mempunyai kekuasaan atau fungsi politik, mereka diarahkan dan dikendalikan oleh kelas pertama dengan cara- cara tertentu. Mengenai kelas atau kelompok yang berkuasa dan dikuasai.

Lebih lanjut Mosca menjelaskan bahwa Kelas Pertama (berkuasa) biasanya terdiri dari orang-orang yang sedikit jumlahnya, menerapkan semua fungsi-fungsi politik, memonopoli kekuasaan dengan menikmati segala keuntungan dari kedudukan sebagai pemegang kekuasaan. Kelas yang Kedua

13 Mosca, Gaetano, The Ruling Elite, London: Penguin Book, 1969.

14 Lebih jelasnya lihat Sastroatmodjo, Perilaku Politik, Semarang: IKIP Semarang Press, 1995, hlm. 228. 
(dikuasai), terdiri dari lebih banyak orang, diarahkan dan dikendalikan oleh kelas pertama, dengan cara-cara kurang lebih legal, sewenang-wenang atau dengan kekerasan. Sedangkan Kelas Kedua menyediakan sarana untuk dapat hidup dan bertahan, serta hal- hal lainnya yang sangat penting bagi organisme politik. Kelas penguasa (kekuasaan elite) menurut Mosca adalah sebagai akibat sifat-sifat yang tak terbantahkan dari watak sosial manusia. Selanjutnya dikatakan, bahwa kelas politik yang tidak adaptatif dengan zaman tidak akan bisa mempertahankan diri. Sementara elite lain akan terbentuk dari kalangan yang diperintah, dan dengan perjalanan waktu akan mengambil alih kekuasaan meskipun dengan kekerasan.

Oleh karenanya semua kelompok penguasa harus mempertahankan sistem pewarisan secara turun temurun agar tetap dapat memanipulasi kekuasaannya. Akan tetapi Mosca juga menyadari, bahwa rekruitmen dari kelas mayoritas sangat dibutuhkan demi stabilitas organisasi politik.

Dari pendangan Mosca tersebut jelas bahwa ada sebuah bentuk dominasi dari kelas minoritas terhadap kelas mayoritas. Dalam Kamus Ilmiah Populer ${ }^{15}$ dominasi diartikan sebagai penguasaan, penempatan posisi bagus dan kuat; pengaruh besar. Dalam itilah lain kata "dominasi” diterapkan untuk menunjukkan dominasi posisi negara-negara kota secara individual, minsalnya yang dilakukan oleh negara kota Athena terhadap negara kota lainnya dalam upaya memisahkan negara (political society) dan masyarakat sipil (civil society) ${ }^{16}$.

Kelas penguasa itu adalah negara melalui kekuasaan pemerintahan. Negara, menurut Offe dan Range, tidak memajukan kepentingan tertentu dan tidak beraliansi dengan kelas tertentu. Sebaliknya, yang dilindungi dan dimajukan oleh negara adalah seperangkat peraturan dan hubungan sosial yang dianggap tercakup dalam kekuasaan kelas kapitalis. Negara tidak membela kepentingan satu kelas tertentu, tetapi kepentingan bersama semua anggota masyarakat kelas kapitalis, yang disebut sebagai alat kekuasaan ${ }^{17}$.

5 Pius A. Partant o dan M. Dahlan Al- barry, 1994, Kamus Ilmiah Populer, Arkola, Surabaya.. Halaman 70.

16 Franz Magnis- Suseno, 2003, Dalam Bayangan Lenin, Enam Pemikir Marxisme dari Lenin Sampai Tan Malaka, Gramedia, Jakarta

17 Lihat Suhelmi, 2001; Johnson, 1986; Giddens dan Held, ed., 1987 
Dari sisi politik kekuasaan, dinastiisme mengindikasikan agar "kesalahan" yang diperbuat oleh kepala daerah sebelumnya dapat "diamankan" oleh sosok kepala daerah berikutnya sehingga istri atau saudaranya-lah yang kemudian "harus" menjadi kepala daerah.

Inti masalahnya adalah menyangkut soal kekuasaan. Mengenai kekuasaan, Tawney ${ }^{18}$ berpendapat bahwa:

"Power may defined as the capacity of an individual, or group of individuals, to modify the conduct of other individuals or groups in the manner in which he desires, and to prevent his conduct being modified in the manner in which he does not" (Kekuasaan diartikan sebagai kemampuan individu atau kelompok individu untuk membatasi keinginan kelompok lain, dan mencegah keinginannya dikuasai oleh kelompok lain tersebut).

Kekuasaan selalu ambigu, mempesona sekaligus menakutkan ${ }^{19}$. Mempesona kerena seorang penguasa dapat mengatur dan mengendalikan chaos. Menakutkan karena kekuasaan cenderung busuk, disalahgunakan untuk menindas rakyat, merampas kebebasan rakyat.

Menurut Aristoteles, elit adalah sejumlah kecil individu yang memikul semua atau hampir semua tanggung jawab kemasyarakatan. Definisi elit yang dikemukakan oleh Aristoteles merupakan penegasan lebih lanjut dari pernyataan Plato tentang dalil inti teori demokrasi elitis klasik bahwa di setiap masyarakat, suatu minoritas membuat keputusan-keputusan besar. Konsep teoritis yang dikemukakan oleh Plato dan Aristoteles kemudian diperluas kajiannya oleh dua sosiolog politik Italias, yakni Vilpredo Pareto dan Gaetano Mosca. ${ }^{20}$

Meneurut Pareto, setiap masyarakat diperintah oleh sekelompok kecil orang yang mempunyai kualitas yang diperlukan dalam kehidupan sosial dan politik. Kelompok kecil itu disebut dengan elit, yang mampu menjangkau pusat kekuasaan. Elit adalah orang-orang berhasil yang mampu menduduki jabatan tinggi dalam lapisan masyarakat. Lebih jauh, Pareto membagi masyarakat dalam

Lihat Soeryono Soekanto, 1984, Pengantar Penelitian Hukum, UI Press, Jakarta.

9 Lihat Windhu, I. Marsana, Kekuasaan \& Kekerasan Menurut Johan Galtung . Yogyakarta: Penerbit Kanisius, 1992

20 Ibid. Hal. 34 
dua kelas, yaitu pertama elit yang memerintah (governing elite) dan elit yang tidak memerintah (non governing elit).

Dalam organisasi apapun, selalu ada kelompok kecil yang kuat, dominan dan mampu mendiktekan kepentingannya sendiri. Menurut Czudnowski ${ }^{21}$ bahwa elit adalah mereka yang mengatur segala sesuatunya, atau aktor-aktor kunci yang memainkan peran utama yang fungsional dan terstruktur dalam berbagai lingkup institusional, keagamaan, militer, akademis, industri, komunikasi dan sebagainya.

Sebagaimana dikemukakan oleh Mas'oed dan Colin Mac Andrews ${ }^{22}$, bahwa dalam dalam studi tentang elite politik, yang paling tepat adalah mendefinisikan kekuasaan dalam artian kekuasaan atas hasil. Karena itu kekuasaan adalah probabilitas untuk mempengaruhi kebijaksanaan dan kegiatan Negara, atau (dalam istilah teori sistem) probabilitas untuk mempengaruhi alokasi nilai-nilai secara otoritatif. Seorang pembuat keputusan yang paling berkuasa sekalipun harus memperhitungkan kemungkinan-kemungkinan reaksi dari yang lain.

Mengacu kepada beberapa pendapat pakar tersebut di atas,, terlihat bahwa sebab-sebab dinastiisme dari perspektif hegemoni atau dominasi elit, adalah sebagai berikut:

1. Petahana sebagai kelas elit (governing elite) memiliki peluang yang lebih besar mendominasi proses pemilihan umum sehingga politik dinasti menjadi sulit dihindari;

2. Patahana sebagai kelas elit (governing elite) menjalankan semua fungsi politik, memonopoli kekuasaan, dan menikmati keuntungan yang diberikan oleh kekuasaan;

3. Masyarakat pemilih (non governing elit) diatur dan dikendalikan oleh petahana sebagai kelas elit.

21 Ibid. Hal. 36

22 Mas'oed, Muchtar dan Colin Mac Andrews, Perbandingan Sistem Politik, Yogyakarta, Gadjah Mada University Press, 1990: 76 - 83. 


\section{Pemilihan Umum}

Sebagaimana dikemukakan oleh Gaffar $^{23}$ bahwa dalam suatu negara demokrasi pemilihan dilaksanakan secara teratur, setiap warga negara yang telah dewasa mempunyai hak untuk memilih dan dipilih dan bebas menggukan haknya tersebut. sesuai dengan kehendak hati nuraninya. Dia bebas untuk menentukan calon atau partai politik mana yang akan didukungya tanpa ada rasa takut atau paksaan dari orang lain pemilih juga bebas mengikuti segala macam aktivitas pemilihan termasuk didalamnya kegiatan kampanye dan menyaksikan perhitungan suara. Tentu saja pemilu adalah sebagai mekanisme dalam menyeleksi pemimpin yang dipilih oleh rakyat.

Dalam pandangan Hutington ${ }^{24}$ seleksi para pemimpin pemerintah melalui pemilihan umum yang kompetitif oleh rakyat yang diperintah, prosedur utama menurut Hutington ialah para pembuat keputusan puncak dalam pemerintahan diseleksi secara periodik melalui pemilihan umum yang fair, diman para kandidat secara bebas bersaing untuk mendapatkan suara.

Tentu saja seleksi pemimpin pemerintah sebagaimana dimaksud Gaffar dan Huntington adalah seleksi yang berlaku untuk di tingkat pusat (sentral) maupun tingkat daerah (desentralisasi).

Dalam konteks desentralisasi maka salah satu tujuan desentralisasi yang paling universal adalah untuk mendorong terciptannya demokratisasi dalam pemerintah $^{25}$. Pemaknaan asas desentralisasi menjadi perdebatan dikalangan pakar dalam mengkaji dan melihat penerapan asas ini dalam pelaksanaan pemerintahan daerah. Perdebatan yang muncul diakibatkan oleh cara pandang dalam mengartikulasikan sisi mana desentralisasi diposisikan dalam pelaksanaan pemerintahan daerah. Dari pemaknaan asas desentralisasi masing - masing pakar tersebut dapat diklarifikasi dalam beberapa hal, di antarannya : (1) desentralisasi sebagai penyerahan kewenangan dan kekuasaan; (2) desentralisasi sebagai pelimpahan kekuasaan dan kewenangan; (3) desentralisasi sebagai pembagian,

${ }^{23}$ Gaffar, Afan. 2006. Politik Indonesia : Transisi Menuju Demokrasi. Yogyakarta: Pustaka Pelajar. Hlm. 9.

24 Huntington, Samuel P. dan Nelson, M. Joan. 1976. Goals adn Choices: Partisipation in the Conteks of Development. Cambridge, Mass: Harvard University Press. Lihat juga Budiardjo, Miriam \& Tri Nuke Pudjiastuti. 1996. Teori-teori Politik Dewasa Ini. Jakarta : PT. Raja Grafindo Persada. Hlm. 9-11).

25 Ibid 86. 
penyebaran, pemencaran, dan pemberian kekuasaan dan kewenangan; (4) desentralisasi sebagai sarana dalam pembagian dan pembentukan daerah pemerintahan $^{26}$.

Pemerintah (daerah) yang sedang berkuasa memiliki fungsi berdiri di atas semua kepentingan, yang oleh Rasyid ${ }^{27}$ tugas pokok pemerintahan yaitu: Pelayanan (service), pemberdayaan (empowerment), dan pembangunan (development). Pelayanan akan membuahkan keadilan dalam masyarakat, pemberdayaan akan mendorong kemandirian masyarakat, dan pembangunan akan menciptakan kemakmuran dalam masyarakat. Sedangkan menurut Ndraha ${ }^{28}$ fungsi pemerintahan yaitu: Fungsi primer atau fungsi pelayanan (service); Fungsi sekunder atau fungsi pemberdayaan (empowerment), sebagai penyelenggara pembangunan dan melakukan program pemberdayaan.

UU No. 32 Tahun 2004 tidak mengatur soal dinastiisme sehingga petahana legal "mendorong" keluarganya; baik itu istrinya, anaknya, menantunya, untuk mencalonkan diri menjadi Kepala Daerah. Baik petahana maupun non petahana sama-sama memiliki peluang untuk mencalonkan diri, baik melalui jalur partai politik, maupun jalur perseorangan (independen).

Karena posisi jabatannya maka ada peluang dan kesempatan bagi patahana untuk menggunakan jaringan kekuasaannya (birokratik dan finansial) dalam upaya "mendorong" keluarganya menjadi pejabat yang menggantikan posisinya. Dari sini akan terlihat beberapa paktor yang mendukung sehingga dinastiisme dapat berlangsung dan karenanya salah seorang anggota petahana dapat berhasil menjadi pemenang dalam sebuah proses pemilihan umum.

\section{Dinastiisme Petahana}

Tampaknya dinastiisme ${ }^{29}$ yang berbasis pada jejaring politik keluarga masih mendapatkan ruang tersendiri dalam benak para pemilih. Munculnya

Ibid. 79

27 Rasyid, M. Ryaas.2000. Makna Pemerintahan, Jakarta : Yarsif Watampone. Hlm. 59

28 Ndraha, Taliziduhu.2000. Ilmu Pemerintahan (kybernology), Rineka Cipta, Jakarta. Hlm. 85

29 Politik dinasti adalah sistem reproduksi kekuasaan yang primitif karena mengandalkan darah dan keturunan. Selengkapnya lihat Slamet Soemiarno, 2010. Bangsa, Budaya, dan Lingkungan Hidup di Indonesia. Jakarta. Balai Penerbit FKUI. 
dinastiisme mengindikasikan bahwa peran keluarga elit masih sangat dominan di dalam proses pemilu.

Dalam perspektif demokrasi prosedural maka dinastiisme menjadi sulit dihindari, termasuk misalkan istri seorang bupati memiliki peluang dan kesempatan maju sebagai kandidat (kontestan) untuk menggantikan suaminya. Salah satu konsekuensinya adalah, bagi petahana yan mencalonkan istrinya sebagai pengganti dirinya, maka akan sulit untuk menapikan hegemoni atau potensi dominasinya, baik itu melalui jalur kekuatan birokratik maupun kekuatan finansial.

Dikatakan oleh Ilyas ${ }^{30}$ bahwa dinastiisme dapat terjadi di beragam tingkat pemerintahan, baik di pusat atau daerah. Hal senada dikemukakan oleh Muhammad Irham Fuady ${ }^{31}$, bahwa ada potensi abuse of power dalam politik dinasti yang akan menimbulkan korupsi yang diikuti oleh kolusi dan nepotisme. Hal ini sinkron dengan teori Lord Acton bahwa Absolutely power tends to corrupt. Oleh sebab itu, perlu adanya pengawasan baik itu internal dari pemerintah sendiri maupun pengawasan langsung dari rakyat

Dapat disebutkan bahwa dinastiisme senantiasa berkonotasi negatif ${ }^{32}$. Secara tegas Burhanuddin Muhtadi ${ }^{33}$ mengatakan bahwa persepsi publik terhadap dinasti politik di Indonesia masih negatif. Berbeda dengan negara demokratis lainnya seperti di Amerika Serikat, India, Pakistan, dan lainnya. Beda dengan di

30 Moh. Ilyas dalam tulisan di blognya 30 Januari yang berjudul Republik Dinasti. Diunduh 11 Oktober 2012.

31 Muhammad Irham Fuady dalam blognya 29 Agustus 2010 yang berjudul Berkembangnya Dinasti Politik Di Indonesia. Diunduh 10 Oktober 2012.

32 Iman Soleh mengatakan bahwa isu politik dinasti sudah berkembang sejak orde lama. Namun fenomena ini semakin marak ketika memasuki otonomi daerah. Dalam Pilkada, pemenangan dimenangkan keluarga incumbent. Dan yang saat ini marak adalah politik dinasti gaya lama namun dengan cara baru (Tribunjabar.co.id. 1 Oktober 2012 diunduh 10 Oktober 2012). Hal senada dikatakan Mahfud MD dalam VIVAnews 25 Mei 2012 (diunduh 10 Oktober 2012) ; Baca juga Menghadang Politik Dinasti dalam kompasiana.com 26 Juni 2012 ; Baca juga Mengintip Fenomena Politik Dinasti DalamPemilihan Kepala Daerah Kabupaten Kediri, makalah Herda Prabadipta, Universitas Brawijaya Malang, Fakultas Ilmu Administrasi, 2012. Baca juga Politik Dinasti = Feodalisme? Karya Made Budi dalam kompasiana 15 Februari 2012; juga baca Politik Dinasti Ancam Demokrasi karya Afifuddin Acal dalam The Globe Journal 5 Mei 2012. Simak juga pendapatnya Firman Jaya Daeli, Indra Jaya Piliang, Rachlan Nasidik, Dr. Siti Zuhro dalam diskusi radio bertajuk Politik Dinasti di Negeri Demokrasi (sindoRadio 10 Oktober 2012); Baca pula Santi Andriani dalam tulisannya Politik Dinasti Hanya Berimplikasi Negatif (inilah.com. 26 Mei 2012); Jug abaca Politik Dinasti Pemerintahan Indonesia: Kajian Multi Perspektif oleh Anindita Ayu, dkk. Fakultas Ilmu Sosial dan Ilmu Politik, Universitas Indonesia 2010; Politik Dinasti Tidak Menyehatkan Demokrasi (Tribunjabar.co.id 1 Oktober 2012); Politik Dinasti (mediaindonesia.com. 24 September 2012).

33 Tribunnews.com tanggal 24 Mei 2012. 
Indonesia, publik menilai dinasti politik sebagai bagian dari nepotisme untuk melanggengkan kekuasaan.

Amich Alhumami ${ }^{34}$ mengatakan bahwa: politik kekerabatan proses rekrutmennya didasarkan pada sentimen kekeluargaan. Garis kekeluargaan merupakan penentu utama sistem kepemimpinan komunal, sekaligus menjadi pola pewarisan kekuasaan politik. Politik kekerabatan, dibangun di atas basis pemikiran yang bertumpu pada doktrin politik kuno: blood is thicker than water -darah lebih kental daripada air. Doktrin ini menegaskan, kekuasaan --karena dapat mendatangkan kehormatan, kemuliaan, kekayaan, dan aneka social privileges-- harus berputar di antara anggota keluarga dan para kerabat saja. Kekuasaan terdistribusi dan bergerak melingkar di antara pihak-pihak yang memiliki pertalian darah.

Dalam pandangan Akbar Faizal ${ }^{35}$ dinastiisme adalah strategi politik manusia yang bertujuan untuk memperoleh kekuasaan, agar kekuasaan tersebut tetap berada di pihaknya dengan cara mewariskan kekuasaan yang sudah dimiliki kepada orang lain yang mempunyai hubungan keluarga dengan pemegang kekuasaan sebelumnya. Itulah pengertian netral dari dinasti politik. Kalau proses pemilihannya fair dan demokratis serta kepemimpinan yang dijalankannya mendatangkan kebaikan dalam pembangunan dan kesejahteraan masyarakat maka dinasti politik dapat berarti positif. Jika yang terjadi sebaliknya. Benih politik dinasti adalah sistem patrimonial, yang mengutamakan regenerasi politik berdasarkan ikatan genealogis, ketimbang merit sistem, di mana patrimonialistik menjadi terselubung oleh jalur procedural melalui jalur partai politik.

Oleh sebab itulah Djohermansyah Djohan ${ }^{36}$ menyatakan bahwa "keluarga inti kepala daerah tidak bisa mencalonkan diri sebagai calon gubernur, maupun bupati atau wali kota”. Keluarga inti yang dimaksud adalah suami atau istri, dan anak. Bila ada salah satu anggota keluarga masih menjabat kepala daerah, maka butuh satu periode lagi untuk bisa maju sebagai calon kepala daerah. Alasan

Baca Dinasti Politik Lokal Makin Kental (Gatra 18 Februari 2010)

www.akbarfaizal.com. 11 Januari 2012. Diunduh 12 Oktober 2012.

36 Direktorat Denderal Peraturan Perundang-undangan. Kementerian Hukun dan Hak Asasi Manusia.

Pemerintah Tutup Peluang Politik Dinasti. Kamis, 27 Oktober 2011. 
penghapusan dinasti politik agar sistem pemerintahan tidak dikuasai kelompok atau keluarga tertentu. Aturan itu juga untuk menciptakan harmonisasi pemerintahan dan mencegah kepala daerah berikutnya melindungi kepala daerah sebelumnya yang terlibat kasus hukum.

Namun hal tersebut disanggah oleh Arif Wibowo ${ }^{37}$ bahwa seseorang mencalonan diri dalam pemilihan umum kepala derah merupakan hak yang tidak dapat diatur dengan hubungan darah dengan kepala daerah yang sedang menjabat. Soal kekhawatiran oligarki perlu diatur partai soal kepantasan, karena rekrutmen ada di tangan pantai.

Menilik beberapa konsep tersebut di atas yang sudah disajikan maka sesungguhnya dinastiisme petahana merupakah hal yang jamak selama proses pemilihanya jujur dan terbuka, selama yang dicalonkan memang kapabelkompeten-kredibel serta berintegritas, juga selama memang masyarakat pemilih memilih yang bersangkutan bukan atas dasar politik uang.

Penulis masih ingat salah satu pernyataan sekaligus jawaban dari seorang narasumber (saat itu yang bersangkutan sebagai Wali Kota) ketika penulis melakukan riset terkait politik dinasti:" Bagaimana mungkin saya melarang istri saya untuk mencalonkan diri sebagai calon Wali Kota sebab Tuhan saja tidak pernah melarang seseorang termasuk istri saya untuk mencalonkan diri?”***

\section{DAFTAR PUSTAKA}

\section{Buku}

Alfian, 1982. Politik, Kebudayaan, dan Manusia Indonesia. Jakarta: LP3ES.

Ayu, Anindita. dkk. 2010. Politik Dinasti Pemerintahan Indonesia: Kajian Multi Perspektif. Fakultas Ilmu Sosial dan Ilmu Politik. Universitas Indonesia

Budiardjo, Miriam. 1980. Masalah Kenegaraan, Jakarta; Gramedia.

Budiardjo, Miriam \& Tri Nuke Pudjiastuti. 1996. Teori-teori Politik Dewasa Ini. Jakarta : PT. Raja Grafindo Persada.

37 Putri Werdiningsih. Pembatasan Dinasti Politik Bisa Digugat ke MK 11 Juni 2012. http://www.mediaindonesia.com/read/2012/06/06/325567/284/1/-Politikus-PDIP-Pembatasan-DinastiPolitik-Bisa-Digugat-ke-MK. 
Dryzek, John. 2000. Deliberative Democracy And Betond : Liberals, Critics, Contestations. Oxford: Oxford University Press.

Gadjong, Agussalim Andi. 2007. Pemerintah Daerah. Bogor: Ghalia Indonesia.

Gaffar, Afan. 2006. Politik Indonesia : Transisi Menuju Demokrasi. Yogyakarta: Pustaka Pelajar.

Garna, Judistira K. 2009. Metoda Penelitian Kualitatif. Bandung. The Judistira Foundation dan Primco Akademik.

Hardiman, F. Budi. 2009. Demokrasi Deliberatif, Yogyakarta: Kanisius

Huntington, Samuel P. dan Nelson, M. Joan. 1976. Goals adn Choices: Partisipation in the Conteks of Development. Cambridge, Mass: Harvard University Press.

Kuswarno, Engkus. 2009. Fenomenologi. Bandung: Windya Padjadjaran.

Lasswell, Harold D. 1970. Power and Society, New Haven, Yale University Press.

Mas'oed, Muchtar dan Colin Mac Andrews. 1990. Perbandingan Sistem Politik, Yogyakarta: Gadjah Mada University Press.

Mosca, Gaetano. 1969. The Ruling Elite, London: Penguin Book.

Ndraha, Taliziduhu.2000. Ilmu Pemerintahan (kybernology), Rineka Cipta, Jakarta.

Pius A. Partant o dan M. Dahlan Al- barry. 1994. Kamus Ilmiah Populer, Surabaya: Arkola.

Rasyid, M. Ryaas.2000. Makna Pemerintahan, Jakarta : Yarsif Watampone.

Sastroatmodjo. 1995. Perilaku Politik, Semarang: IKIP Semarang Press.

Suhelmi, Ahmad. 2000. Pemikiran Politik Barat, Jakarta: Gramedia Pustaka Utama

Suseno, Franz Magnis. 2003, Dalam Bayangan Lenin, Enam Pemikir Marxisme dari Lenin Sampai Tan Malaka, Jakarta: Gramedia.

Soekanto, Soeryono. 1984, Pengantar Penelitian Hukum, Jakarta: UI Press,

Soemiarno, Slamet. 2010. Bangsa, Budaya, dan Lingkungan Hidup di Indonesia. Jakarta. Balai Penerbit FKUI. 
Van Niel, Robert. 1984. Munculnya Elite Modern Indonesia. Jakarta: Pustaka Jaya.

Windhu, I. Marsana. 1992. Kekuasaan \& Kekerasan Menurut Johan Galtung. Yogyakarta: Kanisius.

\section{Jurnal}

Jurnal FISIP UMRAH Vol. 2, No. 2, 2011 : 115 - 125. Fakultas Ilmu Sosial dan Ilmu Politik. Universitas Maritim Raja Ali Haji. Tanjungpinang .

Jurnal Toddopuli dalam Blog Andriani Salam Kusni \& JJ. Kusni. 18 Mei 2012 Analisis. Tahun XXIII No. 1.

\section{Majalah}

Gatra 18 Februari 2010: Dinasti Politik Lokal Makin Kental

\section{Elektronok}

Wikipedia ensiklopedia bebas.

www.akbarfaizal.com. 11 Januari 2012.

Tribunjabar.co.id. 1 Oktober 2012

VIVAnews 25 Mei 2012

kompasiana 15 Februari 2012.

sindoRadio 10 Oktober 2012.

mediaindonesia.com. 24 September 2012.

Tribunjabar.co.id 1 Oktober 2012.

Tribunnews.com tanggal 24 Mei 2012.

www.akbarfaizal.com. 11 Januari 2012.

www.mediaindonesia.com/read/2012/06/06/325567/284/1/ 